\begin{tabular}{|l|l|l||}
\hline \multicolumn{2}{|c|}{ PublisherInfo } \\
\hline \hline PublisherName & $:$ & BioMed Central \\
\hline \hline PublisherLocation & $:$ & London \\
\hline \hline PublisherImprintName & $:$ & BioMed Central \\
\hline \hline
\end{tabular}

\title{
MRC scientists revolt
}

\begin{tabular}{|l|l|l||}
\hline \multicolumn{2}{|c|}{ ArticleInfo } \\
\hline \hline ArticleID & $:$ & 4752 \\
\hline \hline ArticleDOI & $:$ & $10.1186 /$ gb-spotlight-20030416-01 \\
\hline \hline ArticleCitationID & $:$ & spotlight-20030416-01 \\
\hline \hline ArticleSequenceNumber & $:$ & 104 \\
\hline \hline ArticleCategory & $:$ & Research news \\
\hline ArticleFirstPage & $:$ & 1 \\
\hline \hline ArticleLastPage & $:$ & 4 \\
\hline \hline & & RegistrationDate : 2003-4-16 \\
\hline ArticleHistory & $:$ & OnlineDate \\
\hline \hline ArticleCopyright & $:$ & BioMed Central Ltd2003-16 \\
\hline \hline ArticleGrants & $:$ & \\
\hline \hline ArticleContext & $:$ & 130594411 \\
\hline \hline
\end{tabular}




\section{Pat Hagan}

Email: pat.hagan@btconnect.com

Senior scientists at the National Institute of Medical Research in north London have hit out at the Medical Research Council's plans to close the centre and relocate it to Cambridge.

A letter signed by the heads of all 18 scientific departments at the NIMR in Mill Hill, demanding the withdrawal of the proposals, has been sent to MRC chief executive Sir George Radda.

Angry staff are also promising to lobby Parliament and sympathetic MPs if the MRC does not abandon the plans. They are outraged at the idea of shutting down the institute and call into question the argument, put forward by the MRC sub-committee that drew up the plans, that relocating it to the Addenbrooke's site in Cambridge will lead to better scientific interactions.

Leading scientists who stand to be directly affected by the proposal privately allege it is being rushed through in time for the end of Radda's tenure in September.

"We think this is being rushed through before he retires," said one senior NIMR scientist who wished to remain anonymous. "The whole staff are incensed by the way it's been carried out. What they are destroying is something that works very well and there's no question it would not work as well in Cambridge."

The dispute has arisen in response to a planning document - the MRC Forward Investment Strategy which was posted on the MRC website last week.

The draft consultation document was drawn up by a sub-committee of the MRC Council, established last October to work out a strategy for the MRC's major capital investments over the next 10 years.

Its job was to focus primarily on the four sites where, the MRC felt, the biggest decisions have to be made in the next few years. These are the NIMR at Mill Hill, the research centre at Harwell in Oxford, the facilities at Hammersmith in west London and the Addenbrooke's site, including the Laboratory of Molecular Biology.

In the report, the sub-committee members acknowledged the role the NIMR, which has an annual budget of $£ 27$ million (\$US 42.5 million) and employs more than 700 staff, has played in scientific developments. It also said there was a strong case for retaining investment in the areas of science currently based at the institute.

"NIMR scientists have been responsible for some of the major achievements in 20th century science, including the discovery of the influenza virus, the development of liquid gas chromatography and the discovery of the sex-determining gene," the report said.

But it added the case for retaining the NIMR at its present site and on its present scale was "not compelling." Instead, it should be integrated into "a major multi-disciplinary university/medical school site." In other words, Addenbrooke's. Such a move would not only create a larger-scale research institute but would bring financial benefits, too, it claimed. "Funds released from any reduction in running costs at the new NIMR would be available for new research elsewhere," it said. 
Other key proposals include a new building for the existing Laboratory of Molecular Biology in Cambridge, as the current facilities are over-crowded and poorly ventilated, the possibility of consolidating staff at the Clinical Sciences Centre in Hammersmith into fewer buildings, and potentially a new animal facility at the same site.

But it's the likely closure of the NIMR, set up in 1913, that has attracted most attention. Interested parties have until May 19 to respond and the strategy will then be considered at the July meeting of the MRC Council.

Critics dispute the idea that relocating to Cambridge will foster greater scientific interaction. They argue that already happens at NIMR because it operates largely as an autonomous enterprise.

The senior NIMR researcher who spoke to us insisted that what has angered staff most is that the decision was reached without any consultation. "There was no consultation with us or any outside bodies. This is a major change affecting a very large institution and it's been done with out any experts being consulted.

"There are many reasons why moving to Cambridge is not a good idea but our first line of defence is that the decision was reached by a committee that meets about four times a year and includes the heads of research boards, the very people responsible for assessing how good the science is at the NIMR."

This, he fears, creates a conflict of interest and puts research heads under pressure to find scientific reasons to downsize the institute. "A recent survey showed this building [at Mill Hill] is in very good shape and we've just had one wing renovated for a new neuroendocrinology unit. As for clinical collaboration, it's much more convenient in London than in Cambridge. I don't think people realize how exceptionally well this institute works. "Everybody's under the same roof and you're always bumping into people. You can almost always find someone who has the answer to your question."

It's a view shared by former NIMR researchers. One who worked there as a developmental biologist, but did not want his name disclosed, said: "I did some of my best work there to date. It's a terrific place and produces fantastic science. It's big enough to be autonomous. The truth is people talk a lot about interaction between institutions. But the real collaboration happens along the corridor."

A spokesman for the MRC stressed no decisions had been made and the plans were up for consultation. "It's an invitation to come and talk and any discussions we have are going to be taken on board."

The MRC Council has chosen to consult very openly in order to test the proposals against the views of staff and the scientific community. He stressed the relocation plans should be seen in the context of the whole strategy, rather than in isolation. 


\section{References}

1. National Institute for Medical Research, [http://www.nimr.mrc.ac.uk/]

2. Medical Research Council, [http://www.mrc.ac.uk/]

3. Sir George Radda, [http://www.mrc.ac.uk/index/about-council_members_profiles.htm\#anchor-radda]

4. Houses of Parliament, [http://www.parliament.uk/]

5. MRC Forward Investment Strategy, [http://www.mrc.ac.uk//pdf-fis_consultation.pdf-link]

6. MRC Harwell, [http://www.har.mrc.ac.uk/]

7. MRC Clinical Sciences Centre Hammersmith, [http://www.csc.mrc.ac.uk/]

8. Laboratory of Molecular Biology, [http://www2.mrc-lmb.cam.ac.uk/] 